\author{
St udia Philosophic a \\ Wr a t i s l a vi e n s i a \\ vol. XIV, fasc. 1 (2019) \\ DOI: $10.19195 / 1895-8001.14 .1 .6$
}

\author{
STEFANIA GIOMBINI
}

ORCID: 0000-0002-7398-3023

University of Girona

\title{
Why Sextus? \\ The Pros logikous as Reliable Source for Gorgias' Peri tou mē ontos
}

\begin{abstract}
Two versions of Peri tou mé ontos (ptmo) by Gorgias, related by an Anonymous Author (MXG) and by Sextus Empiricus (SE), have been alternatively accredited by scholars according to their disposition to seek a doctrine or a rhetorical-communicational dimension respectively with the first tendency prevailing. Comparing the ptmo to the rest of Gorgias' works, we verify and clearly demonstrate how SE manages to convey a precise modus argumentandi. In effect, SE shows Gorgias' demonstrative reasoning as employing: (1) the application of demonstrandum and quod erat demonstrandum typical of Gorgias' speeches, reinforced by a substantial and abundant use of verbs of explanation and demonstration, especially in comparison to the rest of the same Against the Logicians' section. Otherwise, MXG reduces this lexicon to the more generic phemmi; (2) the continuous employment of the reductio ad absurdum, like in all of Gorgias' works; (3) a very refined formulation of the principle of non-contradiction ( $\S 67$, similar to the one seen in Pal. 25). In addition, MXG is accurate in the discussion of some arguments (as in the third kephalaion), however, presents as an overcorrected interpreter, more interested in questioning Gorgias than reporting his original text, also directly referring to Zeno, Melissus, and Leucippus. The context of the ptmo in SE's work the structure presented leads us to believe that SE had the text or at least an accurate summary of the ptmo different from MXG. The aims of this paper are: (1) to demonstrate that SE shows well the Gorgianic demonstrative reasoning and, for this specific reason, he is reliable and valuable resource for us; (2) to hypothesise that SE's version is based on an independent (as yet unknown) source.
\end{abstract}

Keywords: Gorgias, De Melisso Xenophane Gorgia, Sextus Empiricus, Peri tou $m \bar{e}$ ontos, demonstrative reasoning 


\section{Premises of a Question}

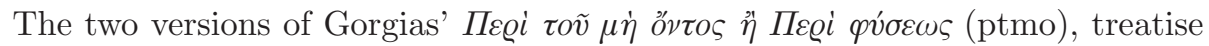

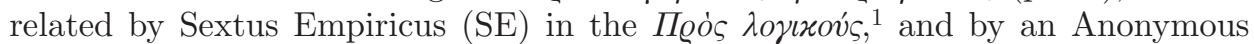
Aristotelian author ${ }^{2}$ in the De Melisso Xenophane Gorgia (MXG), ${ }^{3}$ are accredited by scholars as alternative sources for the understanding of the original text by Gorgias. The preference for either version is decided mainly by an interest in reading the content of the arguments or the rhetoric of the discourse. Irrespective of the preference, it is possible to consider the choice between these two versions according to two fundamental guidelines: those who intend to focus on a philosophical, ontological or linguistic doctrine generally prefer to rely on the MXG text, whilst those who prefer SE are more interested in the rhetorical-communicational dimension. ${ }^{4}$ It should be noted, however, that currently the first tendency is preponder$a^{5} t^{5}$ and the second is less prominent. MXG is therefore generally considered more reliable, especially concerning the profile and the philosophical weight of Gorgias. Indeed, the idea of Gorgias as deeply devoted to philosophy is increasingly popular, while the classification of Gorgias as a rhetorician appears to many as a disparagement of his theoretical contribution to the history of philosophical thought. The critical attitude towards Gorgias was prominent during the second half of the past century; however, such an approach is presently receding and today Gorgias is interpreted, for the most part, as a theoretician in the guise of a rhetorician.

Obviously, MXG is a decisive source but one cannot disregard its highly interpretative character, ${ }^{6}$ a consideration that must also be taken into account regarding

${ }^{1}$ S.E. Adv. math. VII, 65-87.

${ }^{2}$ According to Wesoły, remarking on the correspondences between MXG and the Aristotelian texts, the author could be Aristotle. The hypothesis that the Anonymous Author was an Aristotelian author but not Aristotle is more convincing since MXG appears almost at the level of a refuting exercise. Cf. Wesoły 1983-1984 and 1986. An overview of the hypotheses of the identity of the Anonymous has been offered by Wesoły 2013: 166: "Nel catalogo degli scritti di Aristotele (Diog. Laert. V 25)

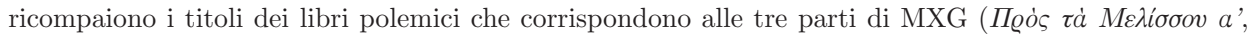

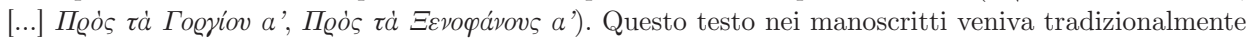
attribuito ad Aristotele, ma solo alcuni interpreti moderni lo hanno considerato come un opuscolo dello Stagirita (Karsten, Mullach); molti, invece, l'hanno inizialmente attribuito a Teofrasto (Bessarione, Brandis, Berg, Kern, Reinhardt, Steinmetz). Solo successivamente è prevalsa l'opinione del Diels, da molti condivisa (Zeller, Gomperz, Robin, Gigon, Kerferd, Wiesner) che pensa ad un peripatetico del terzo secolo, o anche del primo secolo d.C. Successivamente si è parlato di un megarico anonimo (Untersteiner, Reale, Migliori) o di un dossografo anonimo (Cassin). Da ultimo, si è avanzata l'ipotesi di un tardo aristotelico pirronizzante (Mansfeld), e recentemente di un aristotelico molto vicino ad Aristotele (Ioli)." See also Ioli 2010: 23-26 and 2013: 45-47.

${ }^{3}$ De M.X.G., c. 5-6, 979a11-980b21.

${ }^{4}$ For an outline of the interpretative positions see Cunsolo 1996 and the most recent analysis in Bredlow 2016: XXI-XXIV.

${ }^{5}$ Especially starting from Calogero (1932) who supported the superiority of MXG as source. Lately, Ioli 2013, in her last edition of the fragments, argues that MXG is more reliable than SE. Loenen found to the contrary in 1959: $177 \mathrm{ff}$.

${ }^{6}$ Some scholars have discussed the strong interpretative character of the MXG, both its general content and the authors referred to; see, recently, on different fronts: Kurfess 2012: in part. 56-66 and Bremond 2017: in part. 61-95. 
the SE version. ${ }^{7} \mathrm{SE}$ is written by a later, sceptical author, generally polemical and critical, whose thinking is oriented by his interpretations. However, in my opinion, the version by SE should be considered as a credible source for the Gorgias' ptmo on several key points. Firstly, I start from an overall reading of Gorgias according to the idea that he was a pure rhetorician. Gorgias does not stop being rhetorical even when he puts forward theses which, from our point of view, belong in the sphere of philosophy. ${ }^{8}$ The ptmo is the only Gorgias' ontological work that we have an access to. From the available sources, it does not appear that the Sophist ever returned to the subject: it still remains to be determined whether this was a deliberate choice or a lack of opportunity. A conscious choice would be a result of his giving up on the discussion. If this were the case, we would be left with a single text. The lack of opportunity or impossibility to address the topic again could be explained by the lack of further arguments or by lack of an interest in continuing the debate. If this were so, one could claim that a "philosophical level" can be traced in Gorgias' thinking but it was not intended to "seriously" deal with any specific theoretical arguments. In the specific case of ptmo, Gorgias aimed to contradict and deconstruct the philosophical-ontological discourse, demonstrating its weaknesses by means of the same arguments as those who had established it. These arguments are mainly the use of argumenta ad absurdum and some other specific tools.

For these reasons I firmly perceive the Gorgianic ptmo as a polemical work in which the author did not intend to adopt a nihilistic or meontological position. Moreover, I claim that philosophical interpretations which aim to argue so do not find support in Gorgias' thought. I believe that such interpretations of Gorgias are due to the influence of the MXG's Anonymous.

\section{How to Demonstrate (According to Gorgias)}

Putting other works by Gorgias, i.e., the Encomium of Helen, the Apology of Palamedes and the Epitaph within the context of the treaty ptmo, encounters a major problem because these works do not concern the ontological issue. In these works, one can find reflections or references to a variety of different topics (including morality, law, anthropology, logic, Greek culture and gnoseology - the truth of discourses and the mechanisms of knowledge based on Empedocles), ${ }^{9}$ but not a specific reference to "what is not" and its construction. On the contrary, if we consider reflections on the truth referred to in these discourses, Gorgias seems to be a moderate realist

7 Janáček wrote that it is impossible to decide which version is the reliable one: "Obgleich die beiden Berichte, der des Sextus und der des MXG, im Ganzen übereinstimmen, gibt es zwischen ihnen im Einzelnen viele Ungereimtheiten formaler wie sachlicher Natur, es fragt sich daher, welcher von ihnen authentisch ist. Diese Frage kann überhaupt nicht beantwortet werden, weil es keine älteren Zeugnisse von der Lehre des Gorgias, insbesondere keine aus seinen Schriften selbst gibt. So bleibt uns nichts anderes übrig, als eine bescheidenere Frage zu stellen, nämlich die, welcher von den beiden Berichten authentischer ist, welcher die Ansichten des Gorgias besser wiedergibt."; cf. Janáček 2008: 4 $(=1932: 14-15)$.

${ }^{8}$ See Giombini 2012. According to Rossetti (2015) and Ramírez Vidal (2016) in the 5th century B.C. "being a philosopher" was not a clear and structured condition.

${ }^{9}$ For an overview of these topics in Gorgias' works, cf. Giombini 2012. 
for whom reality exists and is the yardstick through which things or actions can and should be evaluated. ${ }^{10}$ One could consider that the Eleatic ontology is an ontology realised on a logical level and not defined by the senses. Indeed, Gorgias noted the contradiction of this mismatch. Taking the logical point of view, the Eleatic ontology (in particular, its Melissus' version) reveals its weaknesses and Gorgias aims to deconstruct it. The fact that this deconstruction does not result in the construction of a discourse on non-being maybe due to the fact that either Gorgias did not wish to do so or he failed to establish it. In my opinion, the first option is more plausible. Thus, if the ptmo does not contain any gnoseological or ontological theory, the interconnection between his works has to be found in his arguments. ${ }^{11}$

One of the argumentative modalities most commonly used by Gorgias is that constituted by the demonstrandum and the quod erat demonstrandum. These are formulas in which the rhetorician declares he will demonstrate a thesis " $\mathrm{X}$ " and later, having demonstrated it, he addressed the public (or the reader) by confidently stating that he has just demonstrated that X. This argumentative modality was not completely unknown at the time of Gorgias since we find traces of it also in Hippocrates ${ }^{12}$ and Plato. ${ }^{13}$ Its first real employment, via the specific formula ö $\pi \varepsilon \rho$

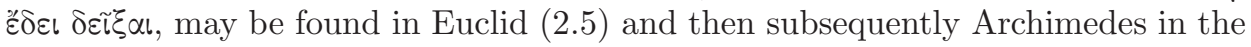
context of mathematical proof. ${ }^{14}$

Gorgias makes an extensive use of this argumentative method, as here below is schematized:

Table 1. Demonstrandum and Quod erat demonstrandum in Gorgias' Epideictic Works

\begin{tabular}{|c|c|}
\hline in the Encomium: & $\begin{array}{l}\S 2 \text { : demonstrandum (Gorgias sets out his intentions about Helen's defence) } \\
\S \S 5 \text {-6: demonstrandum (Gorgias proposes the reasons of the action of Helen) } \\
\S \S 8-9 \text { : demonstrandum (Gorgias asserts that he will prove Helen's innocence, and } \\
\text { will prove it according to the "opinion") } \\
\S 13 \text { : demonstrandum (Gorgias intends to demonstrate how persuasion acts on } \\
\text { the soul) } \\
\S 15 \text { : quod erat demonstrandum (Gorgias claims to have shown the third motiva- } \\
\text { tion, the persuasion of the logos) } \\
\S 19 \text { : quod erat demonstrandum (Gorgias claims to have shown the fourth motiv- } \\
\text { ation) } \\
\S 21 \text { : quod erat demonstrandum (Gorgias claims to have shown Helen's innocence) }\end{array}$ \\
\hline in the Apology: & $\begin{array}{l}\S \S 4-6 \text { : demonstrandum (Palamedes intends to prove his innocence, via two ways } \\
\text { and argues the first; the second is in } \S 13 \text { ) } \\
\S 21 \text { : quod erat demonstrandum (Palamedes claims to have completed the speech } \\
\text { and demonstrated what he had set out, in a very similar manner to } \S 21 \text { of the } \\
\text { Encomium) }\end{array}$ \\
\hline in the Epitaph: & $\begin{array}{l}\S 1 \text { : demonstrandum (programmatic intention of Gorgias about the speech to be } \\
\text { performed) }\end{array}$ \\
\hline
\end{tabular}

Source: own work.

\footnotetext{
10 See: Gorg. Hel. §§1-2; Pal. §5. Cf. Giombini 2012: 127-129, 218-220.

11 Gorgias, indeed, was primarily a rhetorician with many intellectual interests, some of which we can, a posteriori, recognize as philosophical, cf. Giombini 2012.

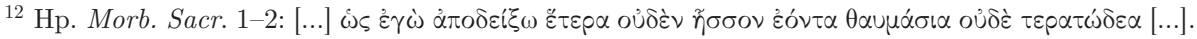
On the demonstrandum see also Rossetti 2006.

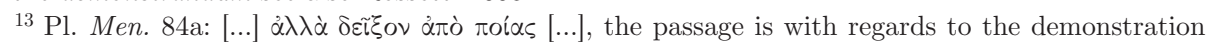
of the duplication of the square.

14 Cf. Mugler 1958: 114.
} 
The ptmo, like the other epideictic works, shows how Gorgias uses these types of argument, and, in my opinion, these specific arguments were understood and trans-

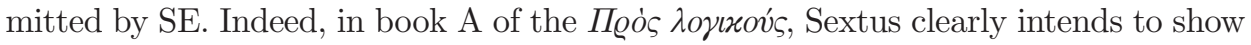
that Gorgias belongs to the ranks of authors who have denied the criterion of knowledge: for this reason, he proposes to adopt the Gorgianic attitude to the demonstrandum and to the quod erat demonstrandum. Obviously, he does not propose it directly, in the first person, as his text is a synthesis of the Gorgianic work and not a direct transcription. Yet, there are significant signs of the adoption of several demonstrative formulas used by Gorgias; a series of references to the reasoning (to be carried out or that has been carried out) exposed through the use of specific verbs.

In $\mathrm{SE}$ a wide spectrum of verbal forms is used which resemble the explanation and the demonstration that can be found in ptmo and in many cases other Gorgianic works: ${ }^{15}$

Table 2. Verbs of demonstration in SE's version of ptmo

\begin{tabular}{|c|c|c|c|}
\hline & & SE's ptmo & Gorgias' Hel. and Pal. \\
\hline SE 1 & $\begin{array}{l}\delta u ́ v \alpha \mu \alpha l \\
\alpha \delta u ́ v \alpha \tau o \nu \\
\left(\dot{\varepsilon} \sigma \tau \tau^{\prime} \nu\right)^{16}\end{array}$ & 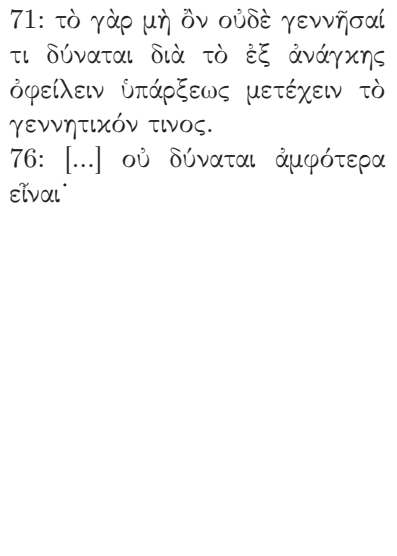 & 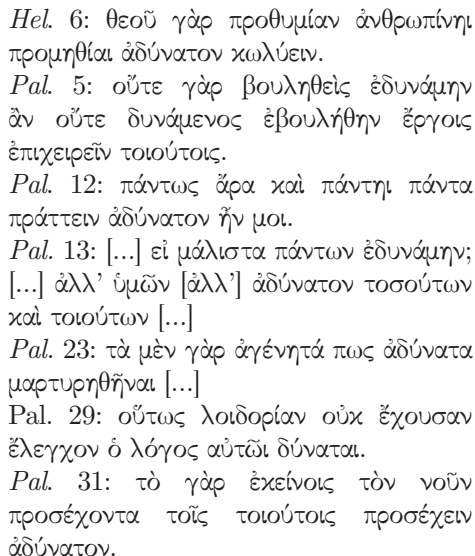 \\
\hline
\end{tabular}

15 An analysis of the lexicon of SE was offered by Classen 1992: $73 \mathrm{ff}$. Classen finds formulas depending on Gorgias in SE: some expressive forms and the use of specific terms, prepositions and conjunctions. If it is true that Classen also considers a series of rather generic terms (as Bredlow 2016: XX, n. 34 points out) it is also true that this type of investigation is the first resource we have to identify Gorgias in SE; and this also applies to the MXG. I will not refer directly to the list of terms identified by Classen, limiting my attention to the forms of the proof. The same kind of analysis was done by Janáček, who included general terms and also genuine terms by SE. Janáček wrote: "Aus allem bisher Gesagten kann man, meine ich, zweierlei erkennen: Sextus drückt die Gedanken des Gorgias durch eigene Worte und in eigener Form aus. Doch nicht nur das - aus dem Vergleich wird ersichtlich, daß er sie auch stark ausdünnt, mit

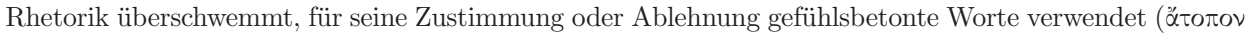

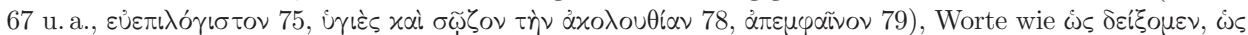
$\pi \alpha \rho \alpha \sigma \tau \alpha \theta \dot{n} \sigma \varepsilon \tau \alpha \iota$ usw. einschiebt. Dies alles drückt eine starke persönliche Anteilnahme des Sextus an der Argumentation des Gorgias, sein Interesse an der Überzeugungskraft von Gorgias' Thesen aus. Nichts von diesen Beitaten kommt in MXG vor, im Gegenteil, die Sprache von MXG ist sachlich, komprimiert, logisch," Janáček 2008: 8 (=1932: 18-19). He recognized that SE pointed out the philosophical and rhetorical ideas of Gorgias but not his method of arguing and demonstrating, but also concluded that: "Die Quelle für Sextus' Bericht über Gorgias festzustellen, ist unmöglich, gerade wegen Sextus' Willkür" (2008: $10=1932$ : 19-20); so, according to him, SE is not a valid source.

16 Cf. Classen 1992: 73. 


\begin{tabular}{|c|c|c|c|}
\hline SE 2 & 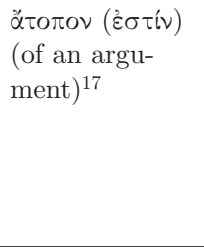 & 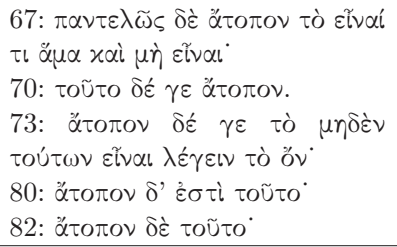 & \\
\hline SE 3 & $\delta \varepsilon i \varkappa \nu \cup \mu \iota$ & 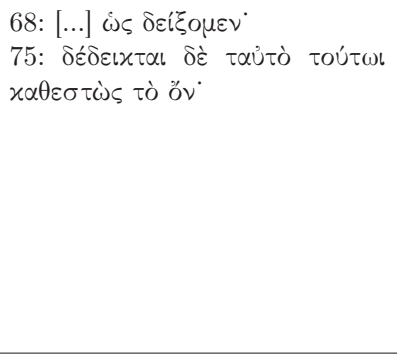 & 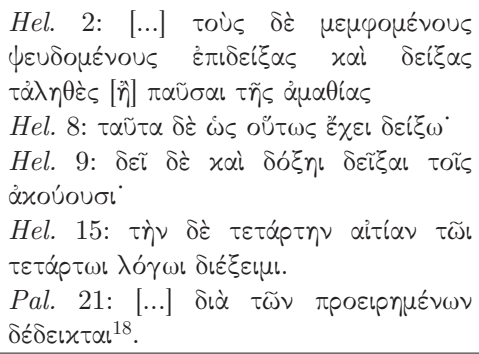 \\
\hline SE 4 & $\delta\llcorner\alpha \delta \eta \lambda o ́ \omega$ & 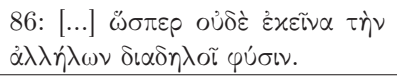 & Cf. MXG 4 \\
\hline SE 5 & $\delta เ \delta \alpha ́ \sigma x \omega$ & 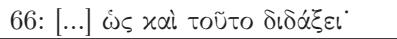 & Pal. 33: [...] $\delta เ \delta \dot{\alpha} \xi \alpha \nu \tau \alpha \tau \dot{\alpha} \lambda \eta \theta \dot{\varepsilon} \varsigma[\ldots]$ \\
\hline SE 6 & $\varepsilon \vee \delta \delta \varepsilon i x \nu U \mu \iota$ & 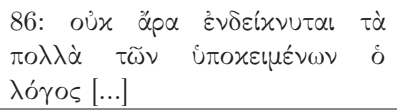 & \\
\hline SE 7 & $\varepsilon \dot{\pi} \iota \lambda o \gamma_{i \zeta}{ }^{\prime} \mu \alpha \iota^{19}$ & 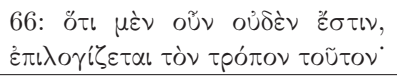 & \\
\hline SE 8 & 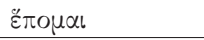 & 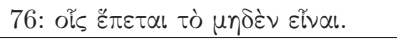 & \\
\hline SE 9 & 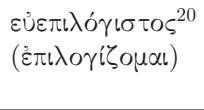 & 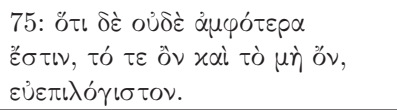 & \\
\hline
\end{tabular}

17 With the variant $\alpha \dot{\tau} \pi \eta \mu_{\alpha}$ in M. 1.80. This verb is also present in Plato's Gorgias: 521d: [...]

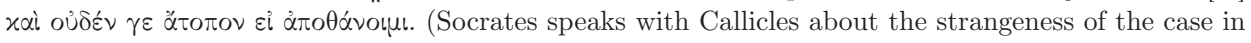
which he could die).

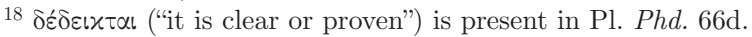

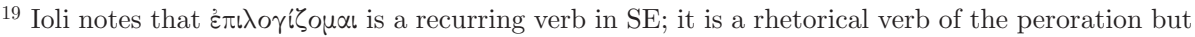
also suitable for the conclusive argumentation, P. I.40, 87, 96; see Ioli 2013: 183. But the verb is more meaningful if we consider that Epicurus and the empiricists used it with intensity (also as opposed to

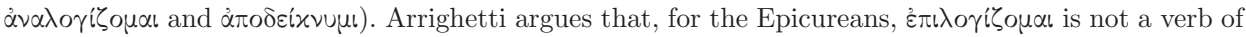
reasoning but a verb that refers to immediate intuition; cf. Arrighetti 1952. For a review of the use of this verb and its forms, mostly connected with Epicurus' basis, see de Lay 1958.

${ }^{20}$ Also in M. 1.297; typically of SE. 


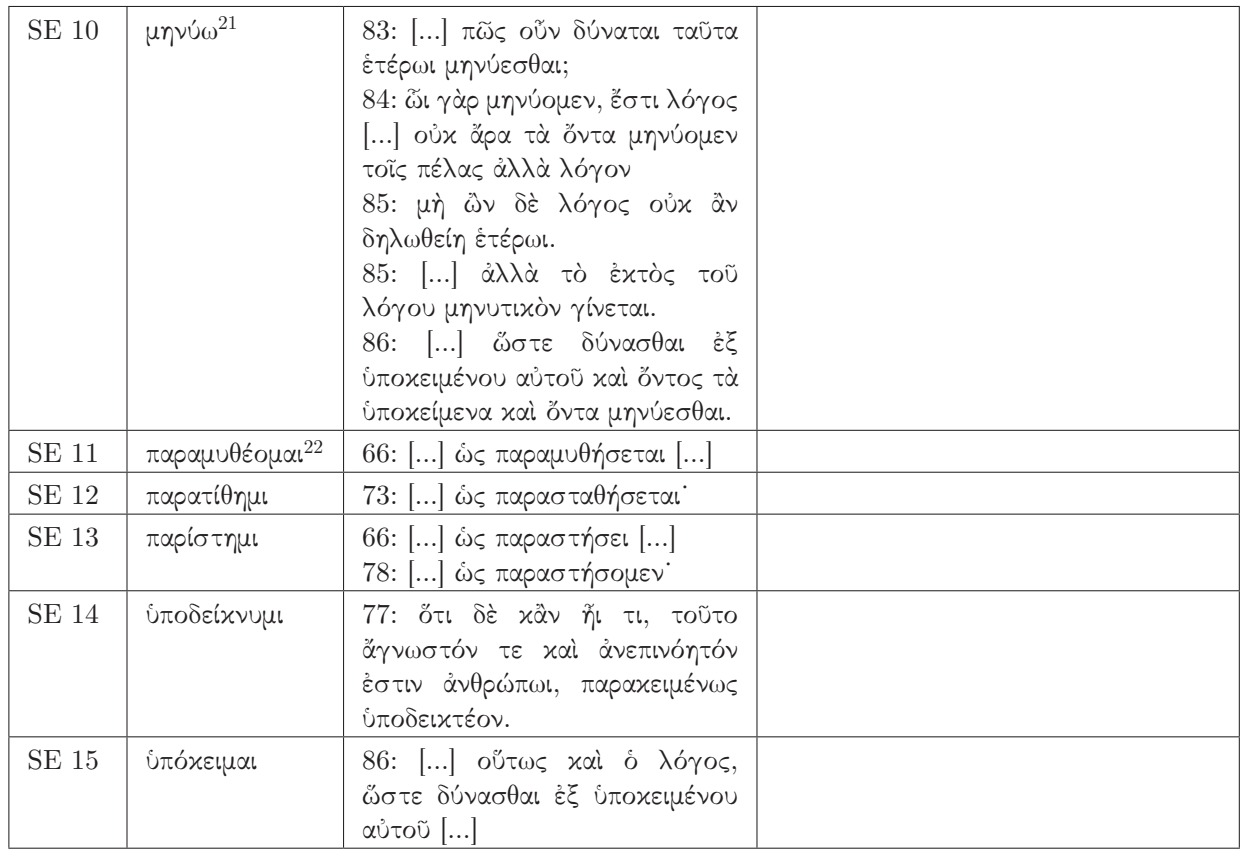

Source: own work.

In Gorgias there are also present two compound forms of $\delta$ cix

Table 3. Verbs of demonstration in Gorgias' Encomium and Apology

\begin{tabular}{|c|c|c|}
\hline G 1 & $\dot{\alpha} \pi 0 \delta \varepsilon \dot{\imath} \chi \nu \cup \mu \iota$ & 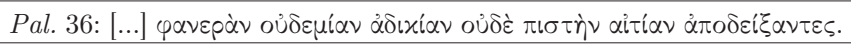 \\
\hline G 2 & 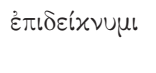 & 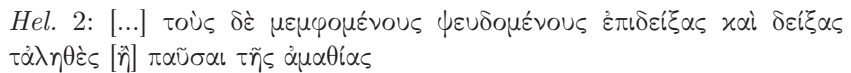 \\
\hline
\end{tabular}

Source: own work.

Indeed, within SE, there is a clear integration of "Gorgianic terms" generic and more commonly used terms, and terms used specifically by him. The presence of verbal forms of demonstration in the treaty by $\mathrm{SE}$ of the Gorgianic ptmo, commands greater interest when one takes into account that such abundant presence

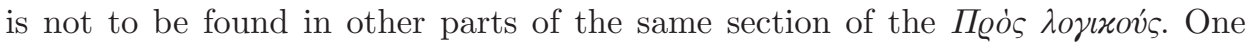
could, therefore, infer that several of these verbs belong to the original Greek text and are not simply introduced by SE arbitrarily, whose work typically does not contain such methods of argumentation. In 1992, Classen noted that SE seems to maintain a greater adherence to the original Gorgianic text within the central part

${ }^{21}$ Gheerbrant (2017: 48-49) notes that, in SE, this verb carries with it the whole force of the sense

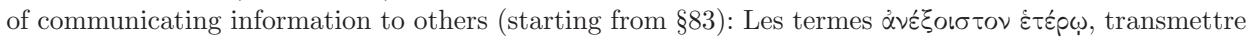

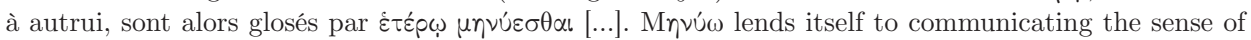
formulating or expressing itself 'avec des mots'.

${ }^{22}$ With the specific meaning of justifying a thesis. 
of his own work, whereas he departs from this, even lexically, at the beginning and end of his speech. ${ }^{23}$

In the MXG's version very little remains of this Gorgianic argumentative modality. In fact, the author of the MXG substantially reduces the lexicon of the demonstration, so much so that the most used verb is a generic $\varphi \eta \mu i$ :

Table 4. Verbs of demonstration in MGX's version of ptmo

\begin{tabular}{|c|c|c|c|}
\hline & & MXG's ptmo & Gorgias' Hel. and Pal. \\
\hline MXG 1 & $\begin{array}{l}\delta u ́ v \alpha \mu \alpha l \\
\alpha \delta u ́ v \alpha \tau o \nu \\
(\varepsilon \sigma \tau i v)\end{array}$ & 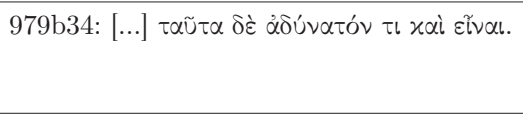 & Cf. SE 1 \\
\hline MXG 2 & $\dot{\alpha} \pi \circ \delta \varepsilon i \varkappa \nu \bar{\nu} \mu \iota$ & 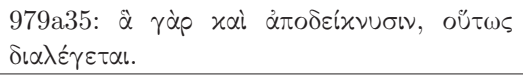 & Cf. G 1 \\
\hline MXG 3 & $\delta \varepsilon i x \nu \cup \mu \iota$ & 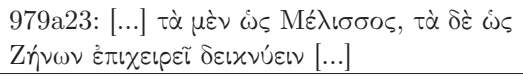 & Cf. SE 3 \\
\hline MXG 4 & $\delta \eta \lambda \omega^{2} \omega^{24}$ & 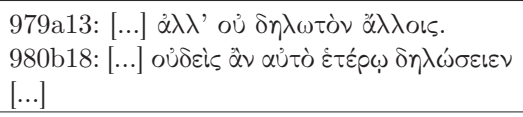 & 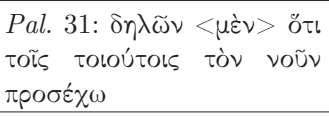 \\
\hline MXG 5 & $\sigma u \lambda \lambda o \gamma i \zeta o \mu \alpha i^{25}$ & 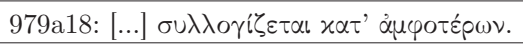 & \\
\hline MXG 6 & $\varphi \eta \mu i$ & 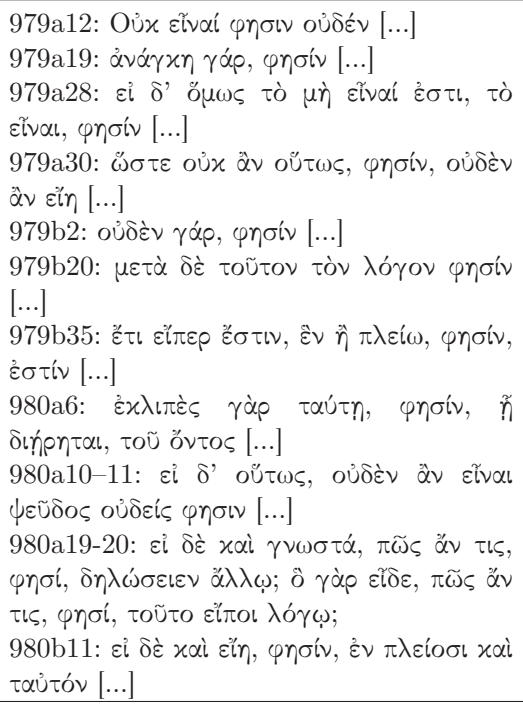 & Cf. SE 16 \\
\hline
\end{tabular}

Source: own work.

${ }^{23}$ Classen 1992: 78: "Accanto a due o tre luoghi nei quali compaiono singoli vocaboli tardi, le espressioni certamente estranee a Gorgia sono più frequenti all'inizio, dove Sesto si serve evidentemente del proprio linguaggio per riassumere brevemente in sede introduttiva la dottrina di Gorgia ( $M$.

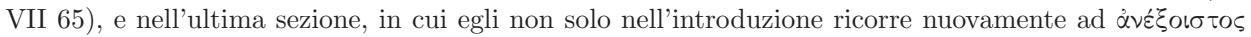
( $M$. VII 83), ma nell'intero paragrafo 85 usa formulazioni autonome."

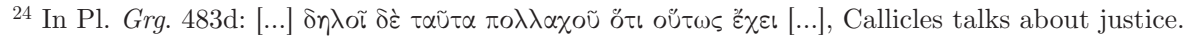

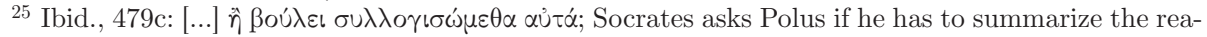

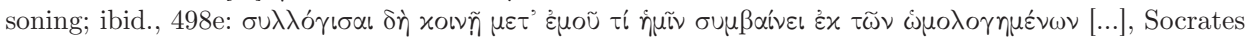
invites Callicles to draw conclusions. 
Ultimately, SE is able to perceive the formal aspects of the Gorgianic epideictic rhetoric, whereas MXG appears decidedly further from the Gorgias known through his other works. Classen reached the same conclusions when he sought the forms of assimilation between Gorgias and SE and felt that SE is a faithful source, also with respect to vocabulary, on the Gorgianic texts. In my opinion, the use of verbs of demonstration in the context of the logical-rhetorical structure of the demonstrandum and quod erat demonstrandum clearly reveal and further strengthen this perspective.

\section{Further Arguments in Support of Sextus}

In addition to the structures of the demonstration, I believe that other aspects of SE's work should be seen as arguments in its favour. In SE's the constant use of the reductio ad absurdum - (an argument used constantly by Gorgias in his other works) - is adequately stressed. The reduction to the absurd had been strongly developed by Zeno of Elea in his paradoxical arguments, but Gorgias used it so extensively that one could say that it is one of the logical arguments most developed by him. The reductio is well suited to the speeches of defence and accusation which has to do with the courts to which Gorgias had shown to have had a certain predilection. ${ }^{26}$ Like SE, even MXG does not avoid the use of the reductio, and could not do so because the disjunctive and paradoxical argumentation is the scaffold of the Gorgianic work. However, in SE reductio is pronounced and evident, whereas in MXG it is discussed, although it is rhetorically unconvincing, which is probably due to the fact that MXG did not aim to show how Gorgias argued and what resulted from his arguments.

Another thing that suggests the superiority of SE's account of Gorgias' work is the fact that he presents, in $\S 67,{ }^{27}$ a formulation of the principle of non-contradiction $(p d n c)$ which is very close to that in $\S 25$ of the Palamedes ${ }^{28}$ In this passage, Gorgias has proposed a rather subtle definition of the principle which can be seen as an antecedent of the Aristotelian one. While it is true that in the Palamedes Gorgias did not provide an abstract definition (because it is devoted to a specific case), SE's ptmo demonstrates a degree of abstraction and universalization that makes Gorgias' formulation of the principle of contradiction even stronger when compared with the Aristotelian formulations. The same principle occurs in different steps of SE, e.g. in $\S 72^{29}$ with a brief passage on the impossibility that some-

${ }^{26}$ Cf. Giombini 2015.

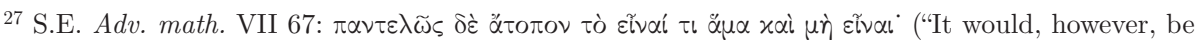
entirely absurd for something to exist and at the same time not to exist; transl. by G. Kennedy, in Kent Sprague 2001).

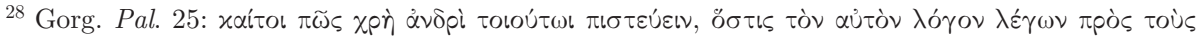

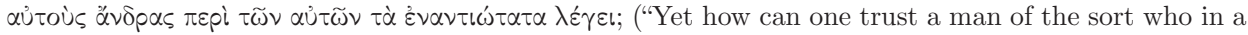
single speech says to the same man the most inconsistent things about the same subjects?"; transl. by G. Kennedy, in Kent Sprague 2001).

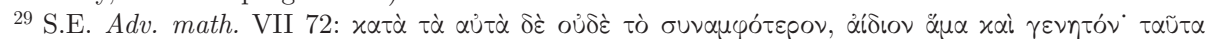

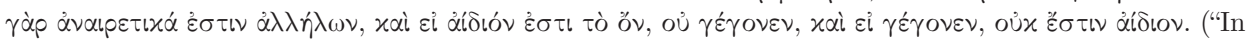




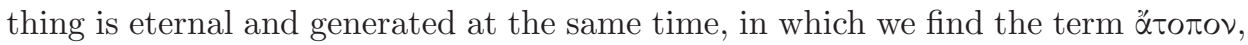
often employed in order to convey the idea the absurdity of reasoning.

In opposition to this, the formulation in MXG does not support the conclusion that 'what is' and 'what is not' cannot be at the same time. Therefore, in MXG the power of the definition of the principle of non-contradiction is lost because the principle is transformed into reflection and interpretation, as in the case of $980 \mathrm{~b} 10 \mathrm{ff} .{ }^{30}$

Moving from form to content, it must be emphasized that the SE's account of Gorgias work is impaired by the intention to support the position of the author. Indeed, SE aims to show that Gorgias intends to deny both the possibility of a gnoseological criterion and its application. In this sense, he appears more "complacent" and less critical even when he is faced with obvious sophism as in $\S 69$, wherein Gorgias makes the problem of generation and eternity of the temporal level interact with the spatial level of the infinite and of the container-content which then follows in $\S 70,{ }^{31}$ ultimately resulting in a rapid and coherent passage, typical of the pressure of the arguments required by rhetoric in the construction of a sophism. ${ }^{32}$

$\mathrm{SE}$ is also more concise in relating the arguments that may not be in line with his analysis as in the third kephalaion. He reduces the treatment to a quick conclusion by underlining the impossibility to communicate the existing reality by means of language, thus allowing him to reaffirm the lack of the criterion in Gorgias'. MXG, instead, devotes a lot of attention to the third kephalaion, which contains the pdnc (and also an exposition of perception-aisthessis - that has evident influence from Empedocles): ${ }^{33}$ the part ending with the denial of the possibility that every man can conceive the speech of another. So, MXG faces the lack of communication directly while SE focuses on the problem of the language-pragmata connection since his interest lies in the unattainability of reality. ${ }^{34}$ In fact, for SE,

the same way it is not jointly at the same time eternal and generated. For these qualities are mutually exclusive of each other, and if the existent is eternal, it has not been generated, and if it has been generated is not eternal"; transl. by G. Kennedy, in Kent Sprague 2001).

30 This is the argument on the impossibility that two subjects can conceive the same thing.

${ }^{31}$ In this regard, MXG (979b20-30) is more concise than SE and breaks the argument. In fact, he refers to Melissus on the theme of ungenerated and to Zeno on the theme of space.

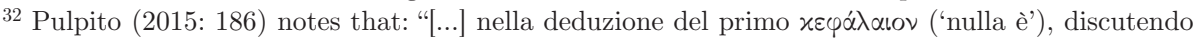
l'ipotesi che qualcosa sia e che sia eterno, Gorgia confonde palesemente l'infinità temporale (l'essere da sempre, cioè il non avere un inizio nel tempo) con l'infinità spaziale (l'essere dappertutto e quindi in nessun luogo). Sono manifestamente due cose non assimilabili (non c'è contraddizione nel pensare che una cosa infinita nel tempo possa essere finita nello spazio, come ad esempio il cosmo di Aristotele) e solo l'ambiguità, o più precisamente l'indeterminatezza verbale, può giustificare questo passaggio. [...] Ora, gli equivoci (e gli errori veri e propri) non bastano a ridurre un ragionamento a mera $\gamma u \mu \nu \alpha \sigma i \alpha$ o a capzioso arzigogolo. Si può sbagliare in buona fede. (Tanto più che il primo equivoco fu attribuito anche a Melisso da Aristotele-Soph. El. 6 168b $35=30$ A10 DK-il quale anche per questo lo giudicava un rozzo ragionatore. Nonostante ciò, la maggioranza degli studiosi non ha reputato Melisso un erista, ma un pensatore convinto di quel che dice). Ad ogni modo quegli equivoci dovrebbero indurci ad ancora maggiore cautela nei confronti di un'operazione complessa come quella di Gorgia."

${ }^{33}$ Cf. Giombini 2012: 138-141.

${ }^{34}$ See S.E. M II.1-140, cf. Marcacci 2008: 31-36. On the concept of "experience" in SE, see Spinelli 2004. 
admitting the problem of incommunicability means to consider relativism, but due to his sceptical position, these ideas cannot easily be assimilated. ${ }^{35}$ For the same reason, perhaps, he slips quickly even on the previous sophism. This is an obvious limitation considering even if he does not interpret it in the manner of MXG, SE directs and uses the Gorgianic text, noting what is important to him. ${ }^{36} \mathrm{SE}$ wants to accomplish a targeted path, so questions the balance of his information and yet, from our point of view, once this is recognized and properly considered, significant data still remains that may refer us to the original Gorgianic text.

In any case, the problem of the interpretation distortion must also be tackled within the MXG' version. MXG, in fact, appears very accurate in the discussions of the arguments (such as in the development of the third kephalaion) but is more careful to discuss Gorgias rather than to directly report him-also using direct references to Zeno, Melissus and Leucippus. ${ }^{37}$

\section{An Independent Source for Sextus}

As already stated, SE includes Gorgias among the authors who are against the criterion together with Protagoras et al.; and yet, only in the case of Gorgias, there is a comprehensive and exhaustive account given when considering the space dedicated to the other authors in the same section. Such precision and exhaustive discussion suggests that SE had at his disposal an accurate and detailed text of the $p t m o^{38}$ from which he made his own version. One well-received hypothesis is that SE used MXG as a source. However, given the lexical and argumentative issues discussed previously and by the fact that in at least two points SE' version is more informative than that of MXG (autonomy of the second part of $\S 67^{39}$ where SE is

${ }^{35}$ Cf. Ioli 2013: 189.

36 That is to say that Gorgias belongs to the ranks of those who deny the criterion. Significant that, in Outlines of Pyrrhonism 2.18, Gorgias is not included among the authors of the criterion together with Xeniades and Xenophanes but is counted among the supporters of the intellect.

37 These references can only be insertions of the Anonymous since in Gorgias' works there are never direct recalls to other authors.

38 A suggestion to the investigation of the origin of the SE's version was recently offered by Rossetti (2017), who at the end of his study, on p. 170, adds: "[...] Che questo confronto possa valere come indizio in base al quale presumere che Sesto si sia limitato a riprodurre un riassunto dovuto a qualcun altro? Non lo escluderei." I understand and partially agree with the interpretation by Rossetti, but I find no reason to think that the version is not genuinely by SE.

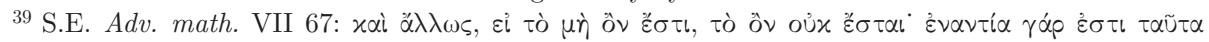

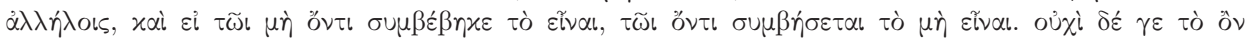

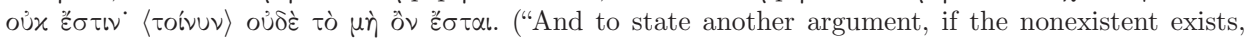
the existent will not exist, for these are opposites to each other, and if existence is an attribute of the nonexistent, nonexistent will be an attribute of the existent. But it is not, in fact, true that the existent does not exist. 'Accordingly' neither will the nonexistent exist"; transl. by G. Kennedy, in Kent Sprague 2001). I do not agree with Bredlow 2016 when he argues that the difference between SE and MXG is a proof of the unreliability of the first. Bredlow writes: "Parece ser asimismo esta parte de la demostración la que refleja el primer argumento, referido por Sexto (§67), en donde, sin embargo, la preocupación exclusiva por refutar el ser de "lo que no es" hace ya sospechar cierta infidelidad a lo que debió de ser el sentido del razonamiento de Gorgias" (2016: XXVII); and also: "De la segunda parte 
much more explanatory and less interpretative ${ }^{40}$ than MXG; or the proof of that "nothing is" in the second part of $\S 76^{41}$ ) this hypothesis is seems unsupported.

It is also possible to consider the two versions as a direct result of the same

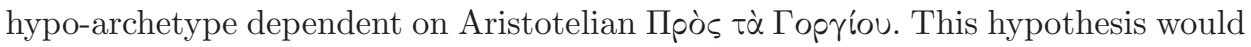

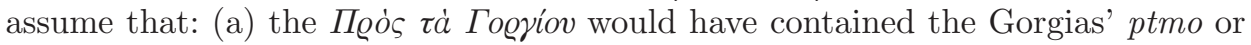
its careful refutation but on a strict textual basis - and on this every hypothesis is really conjectural; (b) this text would have arrived (i.e., it was available) through a hypo-archetype, in some manner, to both the authors active in different periods; (c) admitting (b), using the same text, the authors would have summarized it by selecting only the parts of interest re-elaborating them to their liking (e.g., SE would have even eliminated Gorgias' own argument). The degree of variability between these assumptions, as well as their highly hypothetical nature, opens the door to distinct and possible future ideas of equal complexity. Nevertheless, I propose to claim that SE has been able to take advantage of a text independent or different from the virtual hypo-archetype. It is true that we have no trace of such text, however, given to the specific nature of the SE's version discussed herein, one can speculate its possible existence. Finally, I believe that SE's version should be reconsidered of the ptmo as a significant, reliable, and valuable source in the communication of the demonstrative reasoning of Gorgias.

\section{Bibliography}

Arrighetti G., 1952, "Sul valore di epilogizomai, epilogismos, epilogisis nel sistema epicureo," La parola del Passato 7, pp. 119-144.

Bredlow L.A., 2016, Gorgias de Leontinos, De lo que no es o de la naturaleza. Los testimonios, Barcelona.

Bremond M., 2017, Lectures de Mélissos. Édition, Traduction et Interprétation des témoignages sur Mélissos de Samos, Berlin-Boston.

Calogero G., 1932, Studi sull'Eleatismo, Firenze.

Classen C.J., 1992, "L'esposizione dei sofisti e della sofistica in Sesto Empirico," Elenchos 13, pp. 57-79.

Cunsolo C., 1996, "L'opera 'Sul non essere' di Gorgia. Uno sguardo alle maggiori linee interpretative della critica," Bollettino della Società Filosofica Italiana 158, pp. $7-17$.

de esta prueba sextiana contra "ambos" (§76: "si son ambos, no son lo mismo, y si son lo mismo, no son ambos") no hay traza en el Anónimo, lo que permite dudar de que algo parecido se encontrara en el tratado de Gorgias" (2016: XXXIII). In my opinion, the interpretative dimension in SE does not permit us to directly believe the reliability of MXG.

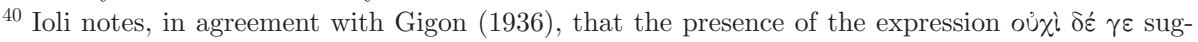
gests that the passage is a gloss by SE. On the contrary, Kerferd 1955: 15-16, assumes the possibility that the passage is not just a simple reflection introduced by SE. Cf. Ioli 2013: 184-185.

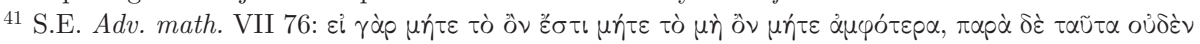

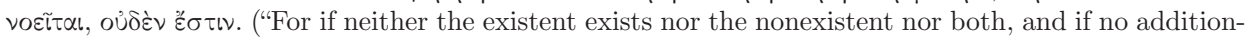
al possibility is conceivable, nothing exists"; transl. by G. Kennedy, in Kent Sprague 2001). 
de Lacy P., 1958, "Epicurean Epilogismos," The American Journal of Philology 79, pp. 179-183.

Gheerbrant X., 2017, Empédocle, une poétique philosophique, Paris.

Gigon O., 1936, "Gorgias 'Über das Nichtsein,'” Hermes 71, pp. 186-213.

Giombini S., 2012, Gorgia Epidittico. Commento filosofico all' Encomio di Elena, all'Apologia di Palamede, all'Epitaffio, Perugia.

Giombini S., 2015, "Gorgia esperto di diritto," [in:] Schegge di filosofia antica e medioevale, I. Pozzoni (ed.), Villasanta, pp. 65-77.

Ioli R., 2009, "Gorgia scettico? Una riflessione sulla presenza del sofista nelle opere di Sesto Empirico," Rheinisches Museum für Philologie 152 [3-4], pp. 331-57.

Ioli R. (ed.), 2010, Gorgia di Leontini. Su ciò che non è, Hildesheim-Zürich-New York.

Ioli R., 2013, Gorgia. Testimonianze e frammenti, Roma.

Janáček K., 2008, "Analyse der Berichte über die Philosophie des Gorgias (1932)," [in:] Studien zu Sextus Empiricus, Diogenes Laertius und zur pyrrhonischen Skepsis, J. Janda, F. Karfik (eds.), Berlin-New York, pp. 1-26.

Kent Sprague R. (ed.), 2001, The Older Sophists, Indianapolis-Cambridge.

Kerferd G.B., 1955, "Gorgias on Nature or That Which Is Not," Phronesis 1 [1], pp. 3-25.

Kurfess C.J., 2012, Restoring Parmenides's Poem: Essays toward a New Arrangement of the Fragments Based on a Reassessment of the Original Sources, University of Pittsburgh, [Doctoral dissertation, not published yet].

Loenen J.H.M.M., 1959, Parmenides, Melissus, Gorgias: A Reinterpretation of Eleatic Philosophy, Assen.

Marcacci F., 2008, "Sesto Empirico e la dimostrazione matematica: momenti di una ricerca," Aquinas 51 [1-2], pp. 29-42.

Mugler Ch., 1958, Dictionnaire historique de la terminologie géométrique des Grecs, Paris.

Pulpito M., 2015, "La versione di Seniade e il parricidio performativo di Platone," [in:] G. Casertano et al., Da Parmenide di Elea al Parmenide di Platone, F. Gambetti, S. Giombini (eds.), Sankt Augustin, pp. 182-191.

Ramírez Vidal G., 2016, La invención de los sofistas, Ciudad de México.

Rossetti L., 2006, "Oltre il demonstrandum. La dimensione metacognitiva dei testi paradossali nell'età dei Sofisti," Méthexis 19, pp. 125-138.

Rossetti L., 2015, "Storia e preistoria della filosofia: alcune date cruciali," Archai 15, pp. 11-20.

Rossetti L., 2017, "Trilemmi: Il PTMO di Gorgia tra Zenone e Melisso," Peitho. Examina antiqua 8, pp. 155-172.

Sedley D., 1992, "Sextus Empiricus and the Atomist Criteria of Truth," Elenchos 13, pp. 21-56.

Spinelli E., 2004, "L'esperienza scettica: Sesto Empirico fra metodologia scientifica e scelte etiche," Quaestio 4, pp. 25-43.

Wesoły M., 1983-1984, "L'argomento proprio di Gorgia," Annali dell'Istituto Italiano per gli Studi Storici 8, pp. 15-45. 
Wesoły M., 1986, "Le tecniche argomentative di Gorgia intorno alla tesi che nulla esiste," [in:] Gorgia e la Sofistica. Atti del Convegno Internazionale (Lentini-Catania, 12-15 dicembre 1983), L. Montoneri, F. Romano (eds.), Catania, pp. 311-341.

Wesoły M., 2013, "La 'dimostrazione propria' di Gorgia," Peitho. Examina antiqua 4, pp. $159-188$. 